\title{
Optimal Top Marginal Tax Rates under Income Splitting for Couples
}

Stefan Bach

Giacomo Corneo

Viktor Steiner

School of Business \& Economics

Discussion Paper

\section{Economics}

$2011 / 21$ 


\title{
Optimal Top Marginal Tax Rates under Income Splitting for Couples
}

\author{
Stefan Bach, Giacomo Corneo, and Viktor Steiner*
}

October 2011

\begin{abstract}
This paper provides formulas for optimal top marginal tax rates when couples are taxed according to income splitting between spouses, consumption is taxed, and the skill distribution is unbounded. Optimal top marginal income tax rates are computed for Germany using a dataset that includes the tax returns of all German top taxpayers. We find that the optimal top marginal tax rate converges to about $2 / 3$ and convergence obtains at income levels that are substantially higher than those currently subject to the actual top tax rate.
\end{abstract}

Keywords: Optimal income taxation, Top incomes, German income tax.

JEL-Classification: D31, D72, H23.

*Bach: DIW, Berlin. Corneo and Steiner: Free University of Berlin. Address of corresponding author (Corneo): Dept. of Economics, FU Berlin, Boltzmannstraße 20, 14195 Berlin, Germany; e-mail: giacomo.corneo@fu-berlin.de.

Acknowledgement: Helpful remarks by Vidar Christiansen, Katharina Jenderny, Áron Kiss, Thomas Piketty and participants in various seminars are gratefully acknowledged. This paper is part of a research project in which DIW Berlin develops and operates microsimulation models on income and business taxation on behalf of the German Federal Ministry of Finance. The data sets provided in connection with this research project are exclusively used under consideration of the applicable regulations of German data protection provisions and the German law on tax statistics. Results and opinions expressed in this paper are those of the authors and do not necessarily reflect views of the Federal Ministry of Finance or DIW Berlin. 


\section{Introduction}

Recent increases in the income concentration at the top of the distribution and concerns about public debts of unprecedented heights have generated much research and policy interest in the taxation of very high incomes. ${ }^{1}$ Since actual tax codes include a top marginal tax rate that applies to incomes above a certain threshold, a crucial issue for tax policy is to determine what the optimal level of that top marginal tax rate is. The early literature on optimal income taxation delivered a deceiptively simple answer to that question: in its basic model, the optimal marginal tax rate on the highest income level is zero. However, as pointed out by e.g. Tuomala (1984) and Diamond (1998), the zerotaxation result has to be interpreted with great caution. Its policy application requires ex-ante knowledge of the maximum income subject to taxation and optimal marginal tax rates need not approach zero until very close to that maximum. If one captures government's ignorance about the top income distribution by positing an unbounded distribution of skills, the optimal asymptotic marginal tax rate is instead positive and depends on the shape of the distribution. Saez (2001) offers a formula of such an optimal top marginal tax rate as a function of substitution and income effects as well as the thickness of the top tail of the income distribution. That formula provides an ideal starting point for the analysis of optimal top marginal income tax rates and the way in which tax policy should react to changing trends in top income inequality. ${ }^{2}$

This paper contributes to the literature on optimal tax rates for top incomes by developing novel extensions to Saez's formulas and by providing novel estimations of optimal top tax rates. Existing formulas for the optimal top marginal income tax rate do not distinguish between taxation of singles and taxation of couples. Such a distinction is crucial for tax systems that have joint taxation with income splitting for spouses. Joint taxation of couples with income splitting is practised in various countries, for instance in Germany and France. This paper offers a formula for the optimal top marginal income tax rate under such a tax system and shows how it relates to existing formulas. Furthermore, we examine how the presence of a consumption tax affects the optimal top marginal income tax rate. Our empirical contribution is to employ high-quality data to estimate the optimal top marginal rate of the income tax for the case of Germany. The unique feature

\footnotetext{
${ }^{1}$ On the evolution of top incomes, see Atkinson and Piketty (2010). Early works on the taxation of top incomes are Slemrod (1994) and Feenberg and Poterba (2000).

${ }^{2}$ As documented by Sabirianova Peter et al. (2010), there has been a worldwide decline in top marginal tax rates in the period 1981-2005. However, in the wake of the current financial crisis, some European governments have decided to raise their top tax rates.
} 
of the dataset we use is that it includes all taxpayers in the top percentile of the German income distribution.

When couples are taxed according to the method of joint taxation with splitting, the spouses' incomes are added together and taxed as if each earned one half of their total income. The income cutoff for taxation at the top marginal tax rate is for couples twice the level that applies to single taxpayers. We derive a formula for the optimal top marginal tax rate that depends on the elasticities and income distributions of both couples and singles in the economy. It is shown that in the special case where they have identical asymptotic elasticities, the optimal top tax rate can be written as in Saez (2001) once the Pareto parameter is re-interpreted as a properly modified weighted average of the Pareto parameters of the respective distributions for singles and couples. When consumption is taxed along with income, the optimal top marginal income tax rate has to be adjusted correspondingly. We derive a simple formula that takes the existence of a consumption tax into account which differs from the one mentioned in Saez (2001).

The empirical part of this paper applies the optimal tax fomulas obtained in the theoretical part in order to assess what the optimal taxation of top incomes is in Germany, a country where top taxpayers often are couples and where consumption is relatively heavily taxed. Our computations are based on an administrative dataset that includes the individual tax returns of all taxpayers in the top percentile of the German income distribution of the years 2004 and 2005. Labor supply elasticities for taxpayers at the top of the income distribution are estimated using data from the German Socio-Economic Panel. A microsimulation model is used to compute their burden in terms of consumption taxes. We find that the optimal top marginal tax rate for Germany converges to about $2 / 3$ and that convergence obtains at an income cutoff for singles of about 350,000 $€$. As compared to actual taxation of top incomes in Germany, the optimal asymptotic marginal tax rate is substantially higher and it only applies to a subset of those incomes that are currently subject to the top marginal tax rate of the actual German tax code. ${ }^{3}$

The remainder of the paper is organized as follows. Section 2 extends Saez (2001)'s formulas to the cases of income splitting for spouses and taxation of consumption expenditures. Section 3 implements those formulas empirically for the German case. Section 4 discusses how our findings should be qualified when thinking about policy implications. Section 5 concludes.

\footnotetext{
${ }^{3}$ In 2005, the top marginal tax rate in Germany (inclusive of a solidarity surcharge) was about $45 \%$ and started at an income level of about 50,000€ for singles and 100,000 € for couples. Since 2007 there exists an additional tax for incomes above $250,000 €(500,000 €$ for couples $)$; the resulting top marginal tax rate is about $48 \%$.
} 


\section{Two simple extensions}

As in Saez (2001), each household has a well-behaved utility function, defined on consumption and leisure, that can be written as $u(c, y)$, where $c$ is consumption and $y$ is earnings, the only source of income in this model. Households differ according to their productivity, which is their private information. Since we are only concerned with top earners and assume that the social planner does not care about their marginal utility, no additional assumption about households' preferences is necessary. In particular, they can be different for singles and couples. However, we assume that couples behave as a unitary decision maker, which is a standard assumption in the taxation literature but has not gone undisputed. ${ }^{4}$ We first introduce couple taxation and then a consumption tax. Whenever useful we attach an index $S$ to variables that relate to single households and an index $C$ to variables that relate to couples.

\subsection{Income splitting for spouses}

There is a continuum of households whose mass is normalized to unity. Households may be either single persons or couples. Let $\mu$ denote the share of couples in the population of tax units. The income of single individuals is taxed according to the tax schedule $T(y)$, while couples are taxed jointly with income splitting between spouses. A couple with income $y$ pays income tax equal to $2 T(y / 2)$.

The government sets a constant marginal tax rate $\tau$ above a cutoff level of income $\bar{y}$. The income tax paid by single individuals with $y \geq \bar{y}$ equals $T(\bar{y})+\tau(y-\bar{y})$. Couples are only affected by the top marginal rate if their income exceeds $2 \bar{y}$. In that case, their income tax liability amounts to $2 T(\bar{y})+\tau(y-2 \bar{y})$. For both household types, consumption is related to earnings through $c=y-T(y)$. Thus, the consumption level of singles in the top tax bracket is given by

$$
c=y(1-\tau)+R
$$

where

$$
R=\tau \bar{y}-T(\bar{y})
$$

Consumption of couples with $y \geq 2 \bar{y}$ is similarly given by

$$
c=y(1-\tau)+2 R
$$

Households in the top income tax bracket choose their earnings so as to maximize their utility function subject to their respective budget constraints, (1) for singles and

\footnotetext{
${ }^{4}$ See e.g. Apps and Rees (2009) for a discussion of alternative cooperative and non-cooperative household models.
} 
(2) for couples. The result of the maximization problem is a earnings supply function $y_{S}(1-\tau, R)$ for singles and $y_{C}(1-\tau, 2 R)$ for couples.

In order to derive the optimal tax rate $\tau$, the mechanical and the behavioral effect from a small change $d \tau$ on the tax revenue are considered. The mechanical effect is denoted by $M=(1-\mu) M_{S}+\mu M_{C}$. One has

$$
M=\left[(1-\mu)\left(y_{m S}-\bar{y}\right)+\mu\left(y_{m C}-2 \bar{y}\right)\right] d \tau,
$$

where $y_{m S}$ denotes the mean of incomes above $\bar{y}$ in the income distribution of singles and $y_{m C}$ denotes the mean of incomes above $2 \bar{y}$ in the income distribution of couples.

The behavioral effect $B=(1-\mu) B_{S}+\mu B_{C}$ can be decomposed into two parts. First, there is an overall uncompensated increase $d \tau$ in the marginal tax rate starting from 0 . Second, there is an increase in virtual income equal to $d R=\bar{y} d \tau$ for singles and equal to $d 2 R=2 \bar{y} d \tau$ for couples. By the same steps as in Saez (2001), the resulting reduction in tax receipts due to the behavioral responses equals

$$
B_{S}=-\tau\left(\epsilon_{S}^{u} y_{m S}-\eta_{S} \bar{y}\right) \frac{d \tau}{1-\tau}
$$

for singles and

$$
B_{C}=-\tau\left(\epsilon_{C}^{u} y_{m C}-2 \eta_{C} \bar{y}\right) \frac{d \tau}{1-\tau}
$$

for couples. Parameter $\epsilon^{u}$ is the uncompensated labor supply elasticity and $\eta$ captures the income effect as given by the Slutsky equation.

At the optimal $\tau$, assuming that it is interior, the sum of $M$ and $B$ equals the monetary valuation by the planner of the loss in marginal utility suffered by the top income earners. Assuming that the planner does not care about the marginal utility of top earners - so that the government aims at maximizing the tax revenue collected from those taxpayers - the optimal tax rate is implicitly determined by $M+B=0$ or

$$
\frac{\tau}{1-\tau}=\frac{(1-\mu)\left(y_{m S}-\bar{y}\right)+\mu\left(y_{m C}-2 \bar{y}\right)}{(1-\mu)\left(\epsilon_{S}^{u} y_{m S}-\eta_{S} \bar{y}\right)+\mu\left(\epsilon_{C}^{u} y_{m C}-2 \eta_{C} \bar{y}\right)} .
$$

This is the formula that we employ in the next Section to numerically determine optimal top tax rates for Germany.

Computing $\tau$ from (3) requires knowledge of the actual distribution of top incomes. While such information is available for Germany, in other instances (3) may be too demanding in terms of data availability. Less data-demanding formulas can be derived under additional assumptions. In the following we assume that $(i)$ singles and couples in the top tax bracket do not differ with respect to their compensated and uncompensated elasticities and ( $i i)$ both the top earnings of singles and those of couples are distributed 
according to the Pareto law, but with possibly different Paretian alphas. The assumption that top earnings are Pareto distributed means that there exists an income level $k \in(0, \bar{y}]$ such that

$$
1-F(y)=\left(\frac{y}{k}\right)^{-\alpha}
$$

where $F$ is the cumulative distribution function and $y \geq k$. A distinctive property of Pareto distributions is that the average income above any income threshold is a constant multiple of that threshold, independent of the level of the treshold. Formally, let $Y(y)=$ $\int_{y}^{\infty} s F^{\prime}(s) d s /[1-F(y)]$ denote average income above $y$. By (4), one has

$$
\frac{Y(y)}{y}=\frac{\alpha}{\alpha-1}
$$

Substituting $y_{m S} / \bar{y}=\alpha_{S} /\left(\alpha_{S}-1\right)$ and $y_{m C} / 2 \bar{y}=\alpha_{C} /\left(\alpha_{C}-1\right)$ into (3) and rearranging yields

$$
\tau\left\{\epsilon^{u}\left[\frac{\alpha_{S}(1-\mu)}{\alpha_{S}-1}+\frac{2 \mu \alpha_{C}}{\alpha_{C}-1}\right]-\eta(1+\mu)\right\}=(1-\tau)\left(\frac{1-\mu}{\alpha_{S}-1}+\frac{2 \mu}{\alpha_{C}-1}\right),
$$

where we have posited $\epsilon_{S}^{u}=\epsilon_{C}^{u}=\epsilon^{u}$ and $\eta_{S}=\eta_{C}=\eta$. In the special case $\alpha_{S}=\alpha_{C}=\alpha$, the above expression boils down to

$$
\tau=\frac{1}{1+\alpha \epsilon^{u}-(\alpha-1) \eta}=\frac{1}{1+\epsilon^{u}+(\alpha-1) \epsilon^{c}},
$$

which is the same formula as in Saez (2001). Also if the Paretian alpha differs across household groups, equation (5) yields a solution similar to the one in Saez (2001) but where $\alpha$ is replaced by a function of the alphas in the two distributions. Specifically, the optimal top tax rate can be written as

$$
\tau=\frac{1}{1+\epsilon^{u}+(a-1) \epsilon^{c}},
$$

where

$$
a=\frac{\alpha_{S} \alpha_{C}-\widehat{\alpha}}{\widetilde{\alpha}-1}
$$

In the last expression, $\widehat{\alpha} \equiv\left[(1-\mu) \alpha_{S}+2 \mu \alpha_{C}\right] /(1+\mu)$ is the average alpha per person in the overall population affected by the top tax rate; $\widetilde{\alpha} \equiv\left[(1-\mu) \alpha_{C}+2 \mu \alpha_{S}\right] /(1+\mu)$ is the average alpha per person in a fictive population where the alphas of the two groups have been exchanged.

\subsection{Taxation of consumption}

We now generalize the formula for the optimal top tax rate to the case where also consumption is taxed. In Saez (2001) it is suggested that an optimal income tax rate $\tau$ derived 
from the standard model should be reduced to $(1-t) \tau$ in the presence of a consumption tax at rate $t$. For the sake of comparison, we deal with the case of a model economy with single individuals only; by a completely analogous approach, the obtained result can be generalized to the setting studied above where there are couples taxed according to the splitting method.

In the presence of a proportional consumption tax at rate $t$, household consumption is related to earnings through

$$
c(1+t)=y-T(y)
$$

where $T(y)$ denotes the income tax schedule. The government optimally sets a constant marginal tax rate $\tau_{y}$ above a given level of income $\bar{y}$. Thus, the income tax paid by individuals with $y \geq \bar{y}$ equals $T(\bar{y})+\tau_{y}(y-\bar{y})$. Inserting that income tax in the budget constraint yields

$$
c=\frac{1}{1+t}\left[y\left(1-\tau_{y}\right)+\tau_{y} \bar{y}-T(\bar{y})\right] .
$$

Individuals in the top income tax bracket choose their earnings so as to maximize their utility function $u(c, y)$ subject to (6). That constraint can be written as

$$
c=y(1-\tau)+\widetilde{R}
$$

where

$$
\tau=\frac{\tau_{y}+t}{1+t}
$$

and

$$
\widetilde{R}=\tau \bar{y}-\frac{T(\bar{y})+t \bar{y}}{1+t} .
$$

This way of rewriting the budget constraint allows one to have a model which is equivalent to the one in Saez (2001). Hence, the expressions for the optimal top tax rate derived in that article are valid for the optimal $\tau$ in the current model where consumption is taxed at rate $t$. Using (7), the optimal income tax rate reads

$$
\tau_{y}=\tau-(1-\tau) t
$$

Thus, the adjustment of the optimal income tax formula suggested by Saez (2001) is accurate only in the special case $\tau=1 / 2$ and the difference can be considerable if $\tau \neq 1 / 2$. By way of an example, if $\tau=3 / 4$ and $t=1 / 5$, the optimal $\tau_{y}$ as implied by (8) is $70 \%$ while using the formula $\tau_{y}=(1-t) \tau$ yields $\tau_{y}=60 \% .^{5}$

\footnotetext{
${ }^{5}$ Alternatively, one can express the consumption tax rate in terms of its tax-inclusive base. If one denotes by $\theta$ that tax rate, the household's budget contraint becomes $c /(1-\theta)=y-T(y)$. The equivalent formula to $(8)$ is then $\tau_{y}=(\tau-\theta) /(1-\theta)$.
} 


\section{Estimations for Germany}

We now compute the optimal top tax rate as implied by (3) and (8) for selected levels of the income cutoff $\bar{y}$ in the case of Germany. Since incomes that exceed a relatively low threshold are not subject to social insurance contributions in Germany, those contributions can safely be neglected. ${ }^{6}$ Our computations are based on administrative tax data that include the individual tax returns of all taxpayers in the top percentile of the German income distribution. The dataset that we use can be accessed to through the Research Data Centre of the Federal Statistical Office of Germany. That dataset includes all income components for each individual within a tax unit - a single person or a couple. We use the most recent available information which is the one pertaining to the year 2005. Results for the year 2004 are similar to those for 2005 and are reported in the Appendix.

\subsection{Distribution of top incomes}

The model used in Section 2 depicts earnings from the supply of labor, while capital income and pure profits are neglected. Three measures of labor income can be recovered from our dataset. The first one only includes wages and salaries, i.e. income from dependent employment. The second one adds to wages and salaries the income received from professional services of the self-employed. The third measure additionally includes the income from business enterprise. Going from the first to the third measure, it is likely that an increasing part of measured income can be attributed to capital and economic rents rather than labor. Also risk taking is likely to be a more important determinant of income for the self-employed rather than the wage earners. We shall therefore mainly discuss the results based on our preferred income measure, namely wages and salaries. ${ }^{7}$

Figures 1 and 2 depict for each income measure its distribution in the population of, respectively, singles and couples. Those Figures show the shape of $Y(y) / y$, the ratio of the average income of all incomes above $y$ to $y$. As noted above, that ratio is constant if the underlying income distribution is the Pareto one. Figures 1 and 2 suggest that the top of the German income distribution is rather well described by a Pareto distribution: starting with yearly incomes of about $350,000 €$ for singles and 400,000 € for couples, the $Y(y) / y$

\footnotetext{
${ }^{6}$ The earning threshold in 2005 was about $62,000 €$ for old-age and unemployment insurance and about $42,000 €$ for health-care insurance. Below, we set the minimum cutoff for taxation at the top marginal tax rate at 50,000 $€$. Since the German social security system is of the Bismarckian variety, contributions to the old-age and unemployment insurance only have a minor tax component.

${ }^{7}$ All measures refer to taxable income. We also performed the same empirical exercise using the broader definition of income proposed in Bach et al. (2009). Optimal asymptotic marginal tax rates were very close to the ones obtained here. Optimal top marginal tax rates were somewhat lower in the case of an income threshold between $50,000 €$ and $100,000 €$. Details are available from the authors upon request.
} 


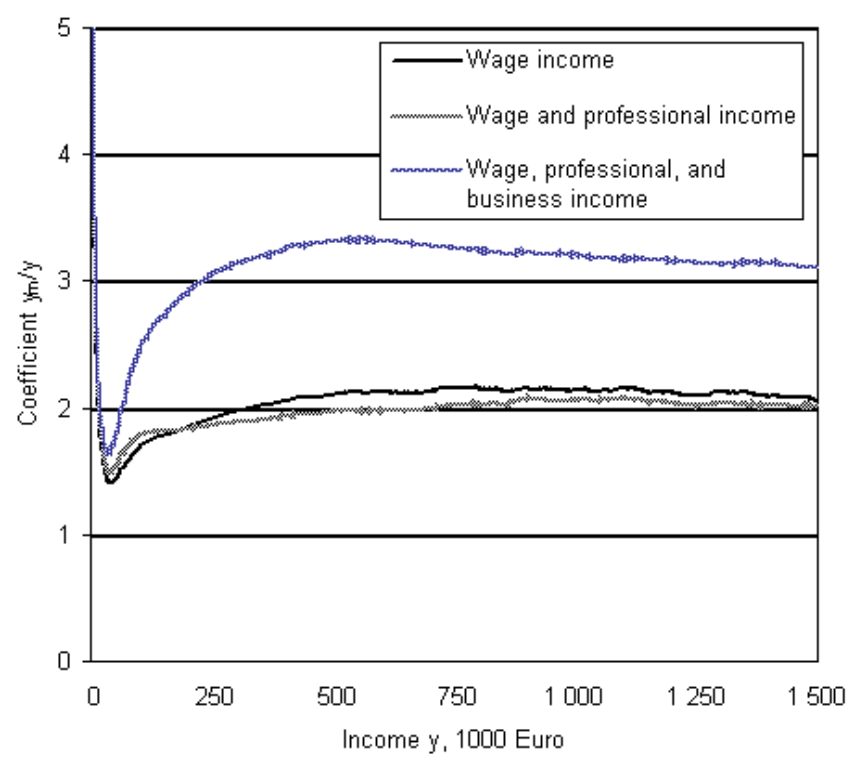

Figure 1: Singles' income distribution

ratio is approximatively constant. However, the level of that ratio is significantly higher for the most comprehensive income measure, the one including income from business enterprise. In terms of Paretian alphas, the $\alpha$ for the income distribution including business income is about 1.5, while excluding it increases the alpha to about 2 .

Tables 1, 2 and 3 show for each income measure the distribution of income above the cutoff $\bar{y}$ for selected numerical values of that cutoff.

\subsection{Elasticities}

We have estimated labor supply elasticities using data from the German Socio-Economic Panel. Separate estimations for singles and couples have been conducted. In the case of couples, the estimation is based on a household utility model. It is assumed that both spouses jointly maximize a utility function that depends on leisure of both spouses and net household income. Working hours include paid overtime and are modeled using the discrete-choice framework proposed by van Soest (1995). Household budget constraints for several hour categories are constructed using a detailed microsimulation model also based on data from the German Socio-Economic Panel. Applying the estimated structural parameters of the model and simulation methods, we have computed compensated and uncompensated wage elasticities of hours worked by households in various intervals of the 


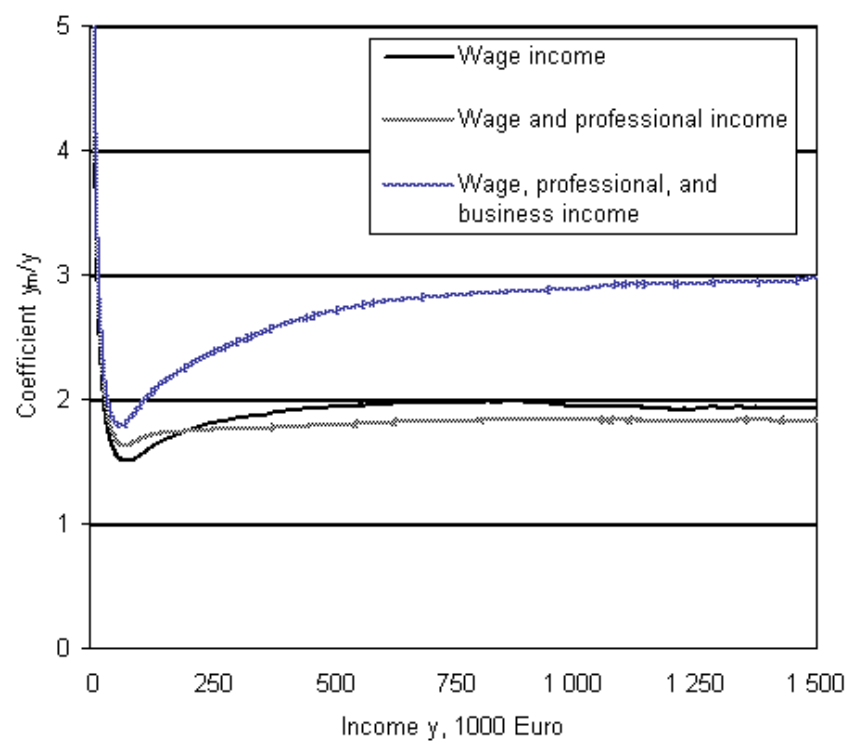

Figure 2: Couples' income distribution

Table 1: Wage Income

\begin{tabular}{|r|r|r|r|r|r|}
\hline Singles & & Couples & & Total & \\
\hline$\overline{\mathrm{y}}$ & nr. of obs. & $2 \overline{\mathrm{y}}$ & nr. of obs & nr. of obs & $\mu$ \\
\hline \hline 50,000 & 913,362 & 100,000 & 523,008 & $1,436,370$ & 0.364 \\
\hline 60,000 & 449,273 & 120,000 & 287,204 & 736,477 & 0.390 \\
\hline 70,000 & 254,915 & 140,000 & 176,736 & 431,651 & 0.409 \\
\hline 80,000 & 159,741 & 160,000 & 119,674 & 279,414 & 0.428 \\
\hline 90,000 & 109,071 & 180,000 & 86,011 & 195,082 & 0.441 \\
\hline 100,000 & 78,537 & 200,000 & 64,191 & 142,728 & 0.450 \\
\hline 200,000 & 12,794 & 400,000 & 11,459 & 24,253 & 0.472 \\
\hline 300,000 & 4,799 & 600,000 & 4,681 & 9,479 & 0.494 \\
\hline 400,000 & 2,497 & 800,000 & 2,549 & 5,046 & 0.505 \\
\hline 500,000 & 1,558 & $1,000,000$ & 1,670 & 3,228 & 0.517 \\
\hline 600,000 & 1,080 & $1,200,000$ & 1,169 & 2,249 & 0.520 \\
\hline 700,000 & 800 & $1,400,000$ & 849 & 1,649 & 0.515 \\
\hline 800,000 & 610 & $1,600,000$ & 642 & 1,252 & 0.513 \\
\hline 900,000 & 493 & $1,800,000$ & 505 & 998 & 0.506 \\
\hline $1,000,000$ & 406 & $2,000,000$ & 417 & 823 & 0.507 \\
\hline $1,100,000$ & 335 & $2,200,000$ & 340 & 675 & 0.504 \\
\hline $1,200,000$ & 294 & $2,400,000$ & 276 & 570 & 0.484 \\
\hline $1,300,000$ & 251 & $2,600,000$ & 232 & 483 & 0.480 \\
\hline $1,400,000$ & 224 & $2,800,000$ & 199 & 423 & 0.470 \\
\hline $1,500,000$ & 205 & $3,000,000$ & 156 & 361 & 0.432 \\
\hline
\end{tabular}


Table 2: Wage and Professional Income

\begin{tabular}{|r|r|r|r|r|r|}
\hline Singles & & Couples & & Total & \\
\hline$\overline{\mathrm{y}}$ & nr. of obs. & $2 \overline{\mathrm{y}}$ & nr. of obs & nr. of obs & $\mu$ \\
\hline \hline 50,000 & $1,048,765$ & 100,000 & 689,177 & $1,737,943$ & 0.397 \\
\hline 60,000 & 546,856 & 120,000 & 418,322 & 965,177 & 0.433 \\
\hline 70,000 & 331,564 & 140,000 & 280,239 & 611,803 & 0.458 \\
\hline 80,000 & 217,146 & 160,000 & 201,656 & 418,802 & 0.482 \\
\hline 90,000 & 157,241 & 180,000 & 151,700 & 308,941 & 0.491 \\
\hline 100,000 & 118,554 & 200,000 & 117,408 & 235,962 & 0.498 \\
\hline 200,000 & 23,324 & 400,000 & 22,468 & 45,792 & 0.491 \\
\hline 300,000 & 9,142 & 600,000 & 8,529 & 17,671 & 0.483 \\
\hline 400,000 & 4,744 & 800,000 & 4,402 & 9,146 & 0.481 \\
\hline 500,000 & 2,876 & $1,000,000$ & 2,679 & 5,555 & 0.482 \\
\hline 600,000 & 1,987 & $1,200,000$ & 1,808 & 3,795 & 0.476 \\
\hline 700,000 & 1,414 & $1,400,000$ & 1,272 & 2,686 & 0.474 \\
\hline 800,000 & 1,051 & $1,600,000$ & 917 & 1,968 & 0.466 \\
\hline 900,000 & 802 & $1,800,000$ & 701 & 1,503 & 0.466 \\
\hline $1,000,000$ & 662 & $2,000,000$ & 569 & 1,231 & 0.462 \\
\hline $1,100,000$ & 541 & $2,200,000$ & 450 & 991 & 0.454 \\
\hline $1,200,000$ & 472 & $2,400,000$ & 369 & 841 & 0.439 \\
\hline $1,300,000$ & 405 & $2,600,000$ & 312 & 717 & 0.435 \\
\hline $1,400,000$ & 352 & $2,800,000$ & 265 & 617 & 0.429 \\
\hline $1,500,000$ & 312 & $3,000,000$ & 211 & 523 & 0.403 \\
\hline
\end{tabular}

Table 3: Wage, Professional and Business Income

\begin{tabular}{|r|r|r|r|r|r|}
\hline Singles & & Couples & & Total & \\
\hline$\overline{\mathrm{y}}$ & nr. of obs. & $2 \overline{\mathrm{y}}$ & nr. of obs & nr. of obs & $\mu$ \\
\hline \hline 50,000 & $1,200,836$ & 100,000 & 810,411 & $2,011,247$ & 0.403 \\
\hline 60,000 & 650,621 & 120,000 & 505,944 & $1,156,564$ & 0.437 \\
\hline 70,000 & 415,316 & 140,000 & 348,158 & 763,474 & 0.456 \\
\hline 80,000 & 271,621 & 160,000 & 256,483 & 528,104 & 0.486 \\
\hline 90,000 & 202,465 & 180,000 & 197,268 & 399,733 & 0.493 \\
\hline 100,000 & 156,860 & 200,000 & 156,574 & 313,434 & 0.500 \\
\hline 200,000 & 39,303 & 400,000 & 37,643 & 76,946 & 0.489 \\
\hline 300,000 & 19,168 & 600,000 & 17,733 & 36,901 & 0.481 \\
\hline 400,000 & 11,995 & 800,000 & 10,912 & 22,908 & 0.476 \\
\hline 500,000 & 8,448 & $1,000,000$ & 7,612 & 16,061 & 0.474 \\
\hline 600,000 & 6,512 & $1,200,000$ & 5,604 & 12,117 & 0.463 \\
\hline 700,000 & 5,303 & $1,400,000$ & 4,403 & 9,706 & 0.454 \\
\hline 800,000 & 4,435 & $1,600,000$ & 3,502 & 7,937 & 0.441 \\
\hline 900,000 & 3,770 & $1,800,000$ & 2,939 & 6,709 & 0.438 \\
\hline $1,000,000$ & 3,265 & $2,000,000$ & 2,531 & 5,796 & 0.437 \\
\hline $1,100,000$ & 2,873 & $2,200,000$ & 2,202 & 5,075 & 0.434 \\
\hline $1,200,000$ & 2,536 & $2,400,000$ & 1,909 & 4,444 & 0.429 \\
\hline $1,300,000$ & 2,300 & $2,600,000$ & 1,724 & 4,024 & 0.428 \\
\hline $1,400,000$ & 2,046 & $2,800,000$ & 1,545 & 3,591 & 0.430 \\
\hline $1,500,000$ & 1,877 & $3,000,000$ & 1,331 & 3,208 & 0.415 \\
\hline
\end{tabular}


income distribution. ${ }^{8}$ For the determination of the optimal top tax rate we are interested in the labor supply elasticity of taxpayers with annual incomes of at least 50,000 $€$ in case of singles and 100,000 $€$ in case of couples. According to our estimations, the average uncompensated labor supply elasticity for singles with income larger than 50,000 € is 0.14 while the income effect amounts to -0.06 . The corresponding parameters for couples with income larger than $100,000 €$ are 0.18 and -0.02 . Those estimates include labor supply responses both along the intensive and the extensive margin. Uncompensated elasticities are somewhat higher for earners with lower income levels. ${ }^{9}$ Lack of data prevents us from further differentiating the extent of behavioral responses within smaller groups at the top of the income distribution.

\subsection{Consumption tax}

Consumption is taxed by means of various instruments in Germany. We have used a microsimulation model based on the German Income and Consumption Survey to estimate the average consumption tax rate for the top decile of the income distribution. The main tax is the VAT at a regular rate of $19 \%$. According to our simulations, roughly $3 / 4$ of the consumption expenditure of the top decile is taxed at the standard rate, the rest being partly subject to the reduced $7 \%$ VAT rate and partly VAT-exempted. To compute the overall tax rate on consumption, we have also taken energy taxation, the insurance tax, taxes on real estate, the motor vehicle tax, taxes on alcohol and tobacco and other quantitatively minor taxes into account. As a result, our simulations suggest that the average consumption tax for the high-income earners amounts to about $20 \%{ }^{10}$

\subsection{Results}

Eq. (3) and (8) imply that the optimal top marginal income tax rate can be written as

$$
\tau_{y}=\frac{A-t}{1+A}
$$

where

$$
A \equiv \frac{(1-\mu)\left(y_{m S}-\bar{y}\right)+\mu\left(y_{m C}-2 \bar{y}\right)}{(1-\mu)\left(\epsilon_{S}^{u} y_{m S}-\eta_{S} \bar{y}\right)+\mu\left(\epsilon_{C}^{u} y_{m C}-2 \eta_{C} \bar{y}\right)} .
$$

\footnotetext{
${ }^{8}$ Details of the microsimulation model are discussed in Steiner and Wrohlich (2008). The estimated elasticities are obtained from data about wage earners. Separate labor supply elasticities for the selfemployed cannot be estimated because of data limitations. The only study that estimates such elasticities without focussing on a special occupation appears to be Parker et al. (2005), where US data is used. The estimated wage elasticities are very close to zero, while labor supply is found to be affected by a self-insurance motive.

${ }^{9}$ They range from 0.25 to 0.3 . Income effects are about -0.07 for singles and -0.02 for couples.

${ }^{10}$ Details of the simulations can be obtained from the authors upon request.
} 
Table 4: Optimal top marginal income tax rates for various thresholds and various income concepts

\begin{tabular}{|l|l|l|l|}
\hline $\bar{y}$ & wage income & $\begin{array}{l}\text { wage and professional } \\
\text { income }\end{array}$ & $\begin{array}{l}\text { wage, professional and } \\
\text { business income }\end{array}$ \\
\hline \hline 50,000 & 0.5621 & 0.6007 & 0.6554 \\
\hline 60,000 & 0.5837 & 0.6157 & 0.6751 \\
\hline 70,000 & 0.6017 & 0.6253 & 0.6875 \\
\hline 80,000 & 0.6144 & 0.6318 & 0.6989 \\
\hline 90,000 & 0.6237 & 0.6348 & 0.7055 \\
\hline 100,000 & 0.6320 & 0.6377 & 0.7111 \\
\hline 200,000 & 0.6621 & 0.6464 & 0.7361 \\
\hline 300,000 & 0.6730 & 0.6546 & 0.7454 \\
\hline 400,000 & 0.6787 & 0.6595 & 0.7490 \\
\hline 500,000 & 0.6780 & 0.6625 & 0.7509 \\
\hline 600,000 & 0.6774 & 0.6620 & 0.7524 \\
\hline 700,000 & 0.6781 & 0.6647 & 0.7524 \\
\hline 800,000 & 0.6794 & 0.6696 & 0.7533 \\
\hline 900,000 & 0.6789 & 0.6730 & 0.7531 \\
\hline $1,000,000$ & 0.6764 & 0.6710 & 0.7525 \\
\hline $1,100,000$ & 0.6775 & 0.6747 & 0.7520 \\
\hline $1,200,000$ & 0.6785 & 0.6743 & 0.7525 \\
\hline $1,300,000$ & 0.6795 & 0.6740 & 0.7511 \\
\hline $1,400,000$ & 0.6783 & 0.6742 & 0.7513 \\
\hline $1,500,000$ & 0.6842 & 0.6798 & 0.7528 \\
\hline & & & \\
\hline
\end{tabular}

Using the empirical findings reported above, we set $t=0.2, \epsilon_{S}^{u}=0.14, \eta_{S}=-0.06$, $\epsilon_{C}^{u}=0.18$ and $\eta_{C}=-0.02$. Optimal top rates are computed for various cutoffs for annual incomes, ranging from $50,000 €(100,000 €$ for couples $)$ to $1,500,000 €(3,000,000$ for couples). Results for all three income measures are reported in Table 4.

Optimal tax rates start at a level close to $56 \%$ for an income cutoff of 50,000 $€$ and converge to a level of about $2 / 3$ for higher income levels. ${ }^{11}$ Convergence is obtained at threshold levels between $300,000 €$ and $400,000 €$. Thus, our findings suggest that the optimal asymptotic marginal tax rate for Germany is about 2/3. A cutoff of at least about $350,000 €$ for singles $(700,000 €$ for couples) would be required to implement an optimal taxation of top incomes, with the remaining components of the German tax system being held fixed.

Our estimations of optimal tax rates are not much affected if the incomes of professionals are included in the income measure. They are significantly larger if the income of business owners is included. That is due to the higher level of concentration of business income, as shown by Figures 1 and 2 .

\footnotetext{
${ }^{11}$ The optimal marginal income tax rates for cutoffs $50,000 €$ and $60,000 €$ in Table 4 are slightly overestimated since we neglect the tax component in the contributions to the old-age and the unemployment insurance that are made by those taxpayers.
} 


\section{Qualifications}

With respect to their policy implications, our results should be qualified in at least two respects. First, the use of labor supply elasticities rather than taxable income elasticities should be discussed. Second, there are determinants of optimal top tax rates that are absent from the theoretical framework on which our estimations are based.

\subsection{Taxable income vs. labor supply elasticities}

We have used elasticity estimates obtained from an investigation of labor supply in Germany. Those elasticities only incorporate the effect of taxation on labor market participation and number of hours worked. Households can however respond to taxation also through other channels affecting e.g. human capital accumulation, choice of career, and effort per hour. Unfortunately, there exists very little direct empirical evidence about the effect of income taxation on those dimensions of taxpayer behavior. Because of conflicting income and substitution effects, one cannot even conclude from theory that traditional labor supply elasticities constitute a lower bound of the overall response of taxpayers. ${ }^{12}$

An alternative to labor supply elasticities that has received much attention in the literature is the elasticity of taxable income with respect to the marginal tax rate. In the modelling framework adopted above, the two elasticity concepts are equivalent. In practice, taxable income elasticity does not only mirror labor market participation and hours but also effort and other dimensions of work intensity that are neglected by labor supply elasticities. Thus, the taxable income elasticity might be a better indicator of the efficiency costs of taxation and a more reliable way to quantify optimal top tax rates. ${ }^{13}$ Empirical elasticities of taxable income are typically larger than labor supply elasticities. For the U.S., Saez et al. (2011) consider the most reliable longer-run estimates to lie in the range from 0.12 to 0.4 , with very small income effects for top incomes. For Germany, Gottfried and Schellhorn (2004) use data from a tax return panel for the years 1988 and 1990. Their preferred estimates of the compensated elasticity range from 0.38 to 0.58 , with somewhat higher values for high income taxpayers who are not wage earners and lower values for top wage earners. However, their estimated elasticities widely vary with

\footnotetext{
${ }^{12}$ In case of long-term decisions about education and career, it is the expected tax rate that matters and there seems to be no attempt to empirically measure those expectations. Notice that the elasticity of expected future tax rates with respect to the actual rate needs not be positive: once the intertemporal budget contraint of the government is taken into account by agents, a higher tax rate today may decrease the tax rate that is expected for tomorrow.

${ }^{13}$ That presumption was forcefully argued by Feldstein (1999). However, Chetty (2009) shows that under plausible conditions taxable income elasticity leads to overstate the deadweight loss of taxation, especially so in the case of taxation of high incomes.
} 
specification and estimation method. Similarly sensitive estimation results are obtained by Gottfried and Witczak (2009), who use data for the years 2001-2004. For taxpayers with an annual income above 50,000 €, they find compensated elasticities of 0.25 for the self-employed and 1.48 for wage earners. For France, Cabannes and Landais (2008) estimate the elasticity of taxable income using an exhaustive panel of top taxpayers in a period during which three large reforms of the tax code took place. They find that the taxable income elasticity for top earners is around 0.15 .

Given the lack of precision with which taxable income elasticities are estimated at the top of the distribution, their use to quantify top tax rates leads to a rather wide spectrum of values. Applying to our data an elasticity of 0.15 - the one found by Cabannes and Landais (2008) - and assuming no income effects yields convergence to an optimal tax rate of $72 \%$. Assuming instead a compensated elasticity of 0.3 and no income effect reduces the asymptotic rate to about $55 \%$, while an elasticity of 0.4 - the upper-bound estimate suggested by Saez et al. (2011) - brings it down to $47 \%$.

The main problem of using the elasticity of taxable income is that it captures reactions that have little to do with efficiency costs and revenue losses for the government. As pointed out e.g. by Saez et al. (2011), reductions in reported incomes may simply be due to a shift away from income subject to the personal income tax to other forms of taxable income, such as corporate income. They may also mirror a shifting of reported income across fiscal years. A similar fiscal externality is present when reductions in reported incomes are due to increased tax evasion: in that case, it is governmental revenue from fining evaders that is bound to increase. ${ }^{14}$ The fiscal externality may also involve a shift of tax liabilities across taxpayers, e.g. in the case of top executives and ordinary shareholders: higher executive compensation after a tax rate cut may be the result of more effort by CEOs to make a bigger intake in the firm's profits at the expense of shareholders' (taxable) returns. The fiscal externality may also take the form of a reduction of public expenditure, as in the case of charitable giving: a decrease of taxable income may mirror increased tax-deductible charitable contributions which in turn reduce the costs of poverty alleviation for the government.

Estimates of the labor supply elasticity neglect some dimensions of taxpayer behavior, like human capital formation and intensity of work, that are implicitly accounted for in the basic model of optimal income taxation and are likely to affect the optimal top

\footnotetext{
${ }^{14}$ Chetty (2009) shows that if taxpayers are rational and risk neutral, the tax revenue lost because of evasion is exactly recouped by increased fines collected by the government. Furthermore, changes in reported incomes may mirror changes in the supply of tax shelters by accountancy firms. As shown by Damjanovic and Ulph (2010), taking the supply side of non-compliance into account, a higher top marginal tax rate can actually improve tax discipline.
} 
marginal tax rate. Estimates of taxable income elasticities have the merit of incorporating responses in terms of changed work intensity. But they also mirror changes in tax evasion, avoidance, and rent-seeking, i.e. reactions that are associated with fiscal externalities. Arguably, many high-income earners face a relatively large set of possibilities of evasion, avoidance and rent-seeking, while they often seem committed to putting much effort into their work. This suggests that labor supply elasticities may be a more reliable instrument than taxable income elasticities to capture the incentive costs of taxation that are relevant for the determination of the optimal top marginal tax rate. Taxable income elasticities may instead be especially useful when assessing the role of loopholes in the tax code and the scope for increased tax auditing.

\subsection{Further determinants of the optimal top tax rate}

Besides the incentive costs of taxation that are at the core of the traditional optimal taxation model, additional factors may significantly affect the socially optimal tax rate for high incomes. We now briefly discuss how that tax rate may be affected by the international mobility of top earners, social externalities related to income polarization, and attitudes toward risk.

\subsubsection{Migration}

A distinctive concern of governments, especially in Europe, is the threat of migration by high income individuals. As shown by Simula and Trannoy (2010), adding the possibility of migration to the standard Mirrleesian model tends to lower the marginal tax rate for top earners. Their simulations for France suggest that the effect from migration is sizeable. ${ }^{15}$ Simula and Trannoy assume that when a top earner migrates, the domestic government loses an amount of tax revenue exactly equal to the income tax that was paid by that top earner. However, it is likely that in reality the fiscal consequences of migration strongly differ according to the occupation of migrants. By way of an example, migration of scientists is more harmful than assumed in the Simula and Trannoy's model if scientists generate positive spillovers on the productivity of their co-workers. Conversely, migration of top managers may have tiny effects on collected taxes if their remuneration is mainly due to informational rents that are necessary to mitigate moral hazard and adverse selection problems. Replacement of the migrated manager by a new one may entail a new equilibrium where only the income tax on the reservation wage - rather than on the manager's compensation - is actually lost by the treasury.

\footnotetext{
${ }^{15}$ However, Young and Varner (2011) empirically estimate migration responses of millionaires to higher income taxation in New Jersey and find only little responsiveness.
} 
Taking the possibility of migration into account tends to lower the optimal top tax rate and points to the contraints for policy makers that result from international tax competition. The threat of migration might be less severe if migration of top earners makes housing more affordable for the poor. As shown by Glazer et al. (2008), if land quality is vertically differentiated and rents are endogenous, a tax which induces emigration of the rich reduces demand for desirable locations, thereby raising the utility of the poor.

\subsubsection{Social and political externalities}

To the extent that a high income concentration creates negative externalities, a higher top tax rate may not only raise more revenue but also improve allocative efficiency. An example of those externalities is when the effort to increase one's income is motivated by a quest for social status or higher relative position. If the marginal utility of consumption is decreasing while the utility from rank is convex, status-seeking motives may be distictively powerful for top income earners - something which is consistent with the observed large number of hours worked by the working rich. The quest for status entails a negative externality since the rank improvement by an individual causes a rank worsening for somebody else. As shown by Boskin and Sheshinski (1978) and Oswald (1983), optimal tax rates are higher when a keeping-up-with-the-Joneses motive is operative; Corneo (2002) shows that a progressive income tax can even generate a Pareto improvement when the Gini coefficient of the distribution of skills is low. In principle, feelings of relative deprivation, as formalized by Yitzhaki (1979), might generate an optimal top tax rate that exceeds the revenue-maximizing one considered in this paper.

Further negative externalities associated with a high level of income concentration are the disproportionate influence of the wealthy in politics and the increase of returns to criminal activity. Corneo (2006) and Petrova (2008) develop models where higher inequality is associated with more media capture; Petrova also offers some empirical support for that prediction. Dahlberg and Gustavsson (2008) discuss the relationship between income inequality and crime and present some empirical evidence suggesting that inequality in permanent income leads to more crime.

\subsubsection{Risk taking}

Under income uncertainty, income taxes generally affect the amount of risk taking by households, while redistributive taxation can generate valuable additional insurance if financial markets are incomplete. ${ }^{16}$ Those aspects can matter for the level of the optimal

\footnotetext{
${ }^{16}$ Early contributions include Eaton and Rose (1980) and Varian (1980); see Boadway and Sato (2011) and Chiu and Eeckhoudt (2010) for recent updates.
} 
marginal tax rate for top earners, the more so as many of them are entrepreneurs or otherwise self-employed individuals subject to considerable income risk.

From the viewpoint of the poor, risk taking by the rich should be encouraged if risk is idiosyncratic and aggregate risk is unaffected. In that case, more risk taking tends to increase aggregate taxable income and tax revenue available for redistribution. If instead individual risks are positively correlated, encouraging risk taking leads to an increase of aggregate risk and there is a trade-off involving the expected tax revenue and its variability. Simply increasing the top marginal tax rate tends to reduce the private gain from taking risk in case of good luck. The resulting effect on individual risk-taking involves conflicting income and substitution effects, whereby the latter is likely to dominate, i.e. a higher top marginal tax rate may adversely affect entrepreneurship. If more risk taking is socially desirable, our estimations of the optimal top tax rate - that neglect risk - may then be too high.

Empirical findings by Cullen and Gordon (2007) suggest that the magnitude of the effect of income taxation on risk taking is small because successful entrepreneurs have the option to incorporate or to avoid high personal income taxes by underreporting their income. Furthermore, when income is uncertain, the government can use a high marginal income tax rate on top incomes in combination with low rates on low incomes in order to provide implicit insurance for potential entrepreneurs and thereby encourage risk taking.

\section{Conclusion}

The enhanced ability to pay of top income recipients makes them an attractive tax base for governments in need of additional revenues. However, the optimal level of taxation of top incomes heavily depends on the shape of the upper tail of the income distribution and on the responsiveness of top taxpayers. This paper has offered a twofold contribution to the literature on the top marginal tax rate that maximizes the tax revenue for the government. First, we have extended existing formulas to the empirically relevant case where couples are taxed according to income splitting between spouses and where not only income but also consumption is taxed. Second, we have used those formulas to compute the optimal top marginal income tax rate for Germany. Estimations based on an exhaustive dataset of top taxpayers suggest that the optimal asymptotic tax rate is close to $2 / 3$ and that a marginal tax rate at that level should be applied only to incomes much larger than those subject to the actual top tax rate. The only incentive effect incorporated in our investigation is the one exerted by a higher top marginal tax rate upon labor supply. Taking the possibility of migration of top earners and the effects of taxation on risk- 
taking into account is likely to reduce the optimal taxation of top incomes in Germany, while taking social and political externalities from income polarization into account is likely to increase it. Incorporating those effects and estimating their magnitudes is an important task for future research. 


\section{APPENDIX: Figures and Tables for 2004}

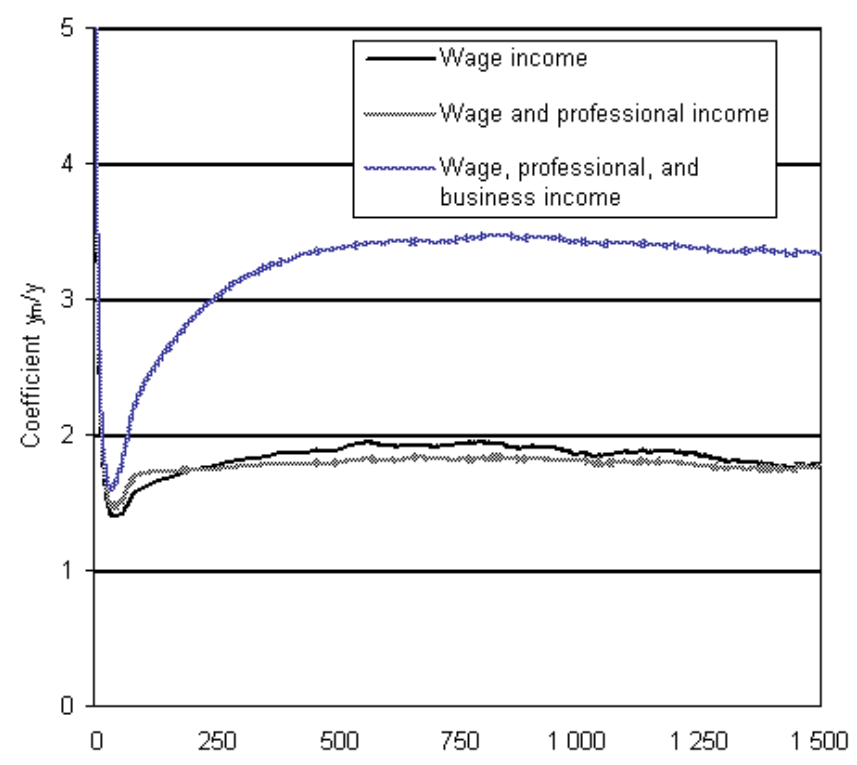

Figure 3: Singles' income distribution

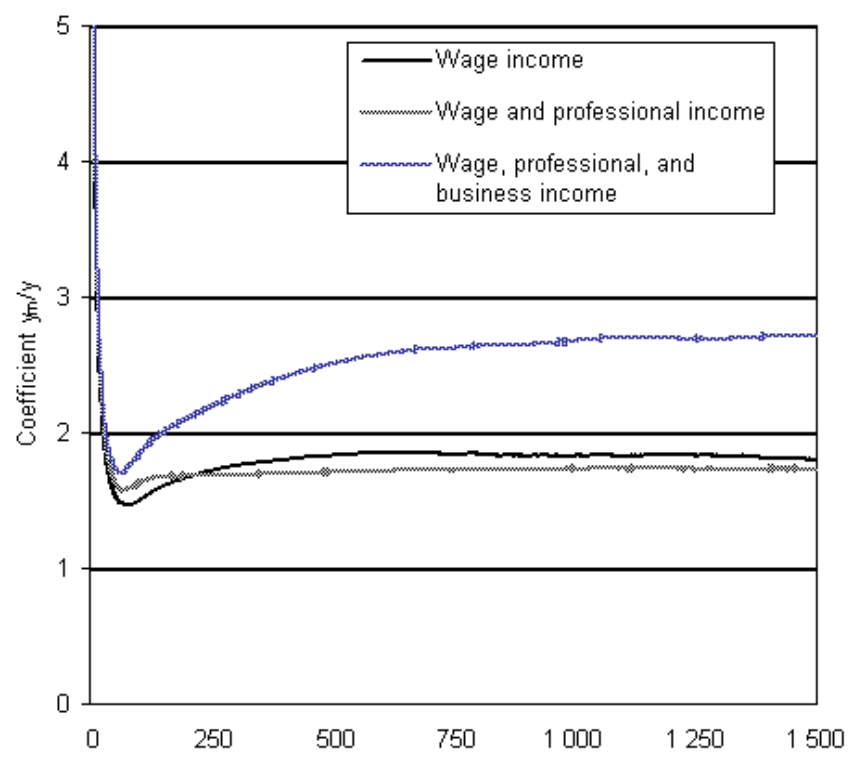

Figure 4: Couples' income distribution 
Table 5: Wage Income

\begin{tabular}{|r|r|r|r|r|r|}
\hline Singles & & Couples & & Total & \\
\hline$\overline{\mathrm{y}}$ & nr. of obs. & $2 \overline{\mathrm{y}}$ & nr. of obs & nr. of obs & $\mu$ \\
\hline \hline 50,000 & 936,510 & 100,000 & 501,249 & $1,437,759$ & 0.349 \\
\hline 60,000 & 493,338 & 120,000 & 268,206 & 761,545 & 0.352 \\
\hline 70,000 & 254,282 & 140,000 & 162,561 & 416,842 & 0.390 \\
\hline 80,000 & 152,765 & 160,000 & 107,845 & 260,610 & 0.414 \\
\hline 90,000 & 101,996 & 180,000 & 76,503 & 178,499 & 0.429 \\
\hline 100,000 & 75,141 & 200,000 & 56,541 & 131,682 & 0.429 \\
\hline 200,000 & 10,931 & 400,000 & 9,261 & 20,192 & 0.459 \\
\hline 300,000 & 3,909 & 600,000 & 3,571 & 7,480 & 0.477 \\
\hline 400,000 & 1,939 & 800,000 & 1,911 & 3,850 & 0.496 \\
\hline 500,000 & 1,177 & $1,000,000$ & 1,185 & 2,362 & 0.502 \\
\hline 600,000 & 775 & $1,200,000$ & 775 & 1,550 & 0.500 \\
\hline 700,000 & 569 & $1,400,000$ & 574 & 1,143 & 0.502 \\
\hline 800,000 & 414 & $1,600,000$ & 424 & 838 & 0.506 \\
\hline 900,000 & 333 & $1,800,000$ & 319 & 652 & 0.489 \\
\hline $1,000,000$ & 284 & $2,000,000$ & 256 & 540 & 0.474 \\
\hline $1,100,000$ & 228 & $2,200,000$ & 210 & 438 & 0.480 \\
\hline $1,200,000$ & 187 & $2,400,000$ & 178 & 365 & 0.488 \\
\hline $1,300,000$ & 172 & $2,600,000$ & 149 & 321 & 0.464 \\
\hline $1,400,000$ & 151 & $2,800,000$ & 126 & 277 & 0.455 \\
\hline $1,500,000$ & 126 & $3,000,000$ & 109 & 235 & 0.464 \\
\hline
\end{tabular}

Table 6: Wage and Professional Income

\begin{tabular}{|r|r|r|r|r|r|}
\hline Singles & & Couples & & Total & \\
\hline$\overline{\mathrm{y}}$ & nr. of obs. & $2 \overline{\mathrm{y}}$ & nr. of obs & nr. of obs & $\mu$ \\
\hline \hline 50,000 & $1,059,231$ & 100,000 & 655,933 & $1,715,164$ & 0.382 \\
\hline 60,000 & 583,474 & 120,000 & 389,477 & 972,951 & 0.400 \\
\hline 70,000 & 328,106 & 140,000 & 258,295 & 586,401 & 0.440 \\
\hline 80,000 & 207,516 & 160,000 & 183,628 & 391,144 & 0.469 \\
\hline 90,000 & 147,827 & 180,000 & 137,072 & 284,898 & 0.481 \\
\hline 100,000 & 113,860 & 200,000 & 105,292 & 219,152 & 0.480 \\
\hline 200,000 & 21,012 & 400,000 & 18,672 & 39,684 & 0.471 \\
\hline 300,000 & 7,827 & 600,000 & 6,847 & 14,674 & 0.467 \\
\hline 400,000 & 3,950 & 800,000 & 3,399 & 7,349 & 0.462 \\
\hline 500,000 & 2,355 & $1,000,000$ & 1,981 & 4,335 & 0.457 \\
\hline 600,000 & 1,526 & $1,200,000$ & 1,265 & 2,791 & 0.453 \\
\hline 700,000 & 1,072 & $1,400,000$ & 885 & 1,957 & 0.452 \\
\hline 800,000 & 789 & $1,600,000$ & 628 & 1,417 & 0.443 \\
\hline 900,000 & 609 & $1,800,000$ & 468 & 1,077 & 0.434 \\
\hline $1,000,000$ & 489 & $2,000,000$ & 374 & 863 & 0.433 \\
\hline $1,100,000$ & 399 & $2,200,000$ & 292 & 691 & 0.423 \\
\hline $1,200,000$ & 328 & $2,400,000$ & 241 & 569 & 0.424 \\
\hline $1,300,000$ & 291 & $2,600,000$ & 211 & 502 & 0.420 \\
\hline $1,400,000$ & 245 & $2,800,000$ & 174 & 419 & 0.415 \\
\hline $1,500,000$ & 201 & $3,000,000$ & 143 & 344 & 0.416 \\
\hline
\end{tabular}


Table 7: Wage, Professional and Business Income

\begin{tabular}{|r|r|r|r|r|r|}
\hline Singles & & Couples & & Total & \\
\hline$\overline{\mathrm{y}}$ & nr. of obs. & $2 \overline{\mathrm{y}}$ & nr. of obs & nr. of obs & $\mu$ \\
\hline \hline 50,000 & $1,193,973$ & 100,000 & 776,414 & $1,970,387$ & 0.394 \\
\hline 60,000 & 671,997 & 120,000 & 475,586 & $1,147,583$ & 0.414 \\
\hline 70,000 & 396,264 & 140,000 & 324,256 & 720,520 & 0.450 \\
\hline 80,000 & 260,795 & 160,000 & 236,304 & 497,099 & 0.475 \\
\hline 90,000 & 191,975 & 180,000 & 180,207 & 372,182 & 0.484 \\
\hline 100,000 & 149,885 & 200,000 & 141,729 & 291,614 & 0.486 \\
\hline 200,000 & 35,047 & 400,000 & 31,773 & 66,820 & 0.475 \\
\hline 300,000 & 16,399 & 600,000 & 14,390 & 30,789 & 0.467 \\
\hline 400,000 & 10,100 & 800,000 & 8,671 & 18,771 & 0.462 \\
\hline 500,000 & 7,066 & $1,000,000$ & 5,915 & 12,980 & 0.456 \\
\hline 600,000 & 5,360 & $1,200,000$ & 4,333 & 9,692 & 0.447 \\
\hline 700,000 & 4,309 & $1,400,000$ & 3,375 & 7,684 & 0.439 \\
\hline 800,000 & 3,511 & $1,600,000$ & 2,678 & 6,188 & 0.433 \\
\hline 900,000 & 2,974 & $1,800,000$ & 2,241 & 5,215 & 0.430 \\
\hline $1,000,000$ & 2,592 & $2,000,000$ & 1,910 & 4,502 & 0.424 \\
\hline $1,100,000$ & 2,273 & $2,200,000$ & 1,640 & 3,913 & 0.419 \\
\hline $1,200,000$ & 2,015 & $2,400,000$ & 1,413 & 3,429 & 0.412 \\
\hline $1,300,000$ & 1,841 & $2,600,000$ & 1,261 & 3,103 & 0.407 \\
\hline $1,400,000$ & 1,653 & $2,800,000$ & 1,116 & 2,770 & 0.403 \\
\hline $1,500,000$ & 1,506 & $3,000,000$ & 988 & 2,494 & 0.396 \\
\hline
\end{tabular}

Table 8: Optimal top marginal income tax rates for various thresholds and various income concepts

\begin{tabular}{|l|l|l|l|}
\hline $\bar{y}$ & wage income & $\begin{array}{l}\text { wage and professional } \\
\text { income }\end{array}$ & $\begin{array}{l}\text { wage, professional and } \\
\text { business income }\end{array}$ \\
\hline \hline 50,000 & 0.5479 & 0.5893 & 0.6421 \\
\hline 60,000 & 0.5598 & 0.5993 & 0.6595 \\
\hline 70,000 & 0.5827 & 0.6123 & 0.6757 \\
\hline 80,000 & 0.5978 & 0.6205 & 0.6872 \\
\hline 90,000 & 0.6077 & 0.6235 & 0.6943 \\
\hline 100,000 & 0.6131 & 0.6242 & 0.6998 \\
\hline 200,000 & 0.6426 & 0.6296 & 0.7289 \\
\hline 300,000 & 0.6531 & 0.6345 & 0.7410 \\
\hline 400,000 & 0.6563 & 0.6375 & 0.7457 \\
\hline 500,000 & 0.6561 & 0.6392 & 0.7485 \\
\hline 600,000 & 0.6602 & 0.6426 & 0.7505 \\
\hline 700,000 & 0.6559 & 0.6426 & 0.7511 \\
\hline 800,000 & 0.6583 & 0.6458 & 0.7528 \\
\hline 900,000 & 0.6590 & 0.6475 & 0.7528 \\
\hline $1,000,000$ & 0.6547 & 0.6450 & 0.7524 \\
\hline $1,100,000$ & 0.6541 & 0.6467 & 0.7526 \\
\hline $1,200,000$ & 0.6517 & 0.6459 & 0.7532 \\
\hline $1,300,000$ & 0.6465 & 0.6368 & 0.7520 \\
\hline $1,400,000$ & 0.6443 & 0.6385 & 0.7525 \\
\hline $1,500,000$ & 0.6444 & 0.6441 & 0.7530 \\
\hline & & & \\
\hline
\end{tabular}




\section{References}

Apps, P. and R. Rees (2009), Public Economics and the Household, Cambridge: Cambridge University Press.

Atkinson, A, and T. Piketty (2010), Top Incomes - A Global Perspective, Oxford: Oxford University Press.

Bach, S., Corneo, G. and V. Steiner (2009), From bottom to top: The entire income distribution in Germany, 1992-2003, Review of Income and Wealth 55, 303-330.

Boadway, R. and M. Sato (2011), Optimal income taxation with uncertain earnings, mimeo.

Boskin, M. and E. Sheshinski (1978), Optimal redistributive taxation when individual welfare depends upon relative income, Quarterly Journal of Economics 92, 589-601.

Cabannes, P.-Y. and C. Landais (2008), The elasticity of taxable income and the optimal taxation of top incomes: Evidence from an exhaustive panel of the wealthiest taxpayers, mimeo, PSE.

Chetty, R. (2009), Is the taxable income elasticity sufficient to calculate deadweight loss? The implications of evasion and avoidance, American Economic Journal: Economic Policy 1, article DOI: 10.1257/pol.1.2.31.

Chiu, W. H. and L. Eeckhoudt (2010), The effects of stochastic wages and non-labor income on labor supply: Update and extensions, Journal of Economics 100, 69-83.

Corneo, G. (2002), The efficient side of progressive income taxation, European Economic Review 46, 1359-1368.

Corneo, G. (2006), Media capture in a democracy: The role of wealth concentration, Journal of Public Economics 90, 37-58.

Cullen, J. B. and R. H. Gordon (2007), Taxes and entrepreneurial risk-taking: Theory and evidence for the U.S., Journal of Public Economics 91, 1479-1505.

Dahlberg, M. and M. Gustavsson (2008), Inequality and crime: Separating the effects of permanent and transitory income, Oxford Bulletin of Economics and Statistics 70, 129-153.

Damjanovic, T. and D. Ulph (2010), Tax progressivity, income distribution and tax non-compliance, European Economic Review 54, 594-607.

Diamond, P. (1998), Optimal income taxation: An example with a U-shaped pattern of optimal marginal tax rates, American Economic Review 88, 83-95.

Eaton, J. and H. Rosen (1980), Labor supply, uncertainty, and efficient taxation, Journal of Public Economics 14, 365-374.

Feenberg, D. and J. Poterba (2000), The income and tax share of very high-income 
households, 1960-1995, American Economic Review (Papers and Proceedings) 90, 264270 .

Feldstein, M. (1999), Tax avoidance and the deadweight loss of the income tax, Review of Economics and Statistics 81, 679-684.

Glazer, A., Kanniainen, V. and P. Poutvaara (2008), Income taxes, property values, and migration, Journal of Public Economics 92, 915-923.

Gottfried, P. and H. Schnellhorn (2004), Empirical evidence on the effects of marginal tax rates on income - the German case, IAW-Diskussionspapier 15, Tübingen.

Gottfried, P. and D. Witczak (2009), The responses of taxable income induced by tax cuts - Empirical evidence from the German Taxpayer Panel, IAW-Diskussionspapier 57, Tübingen.

Moffitt, R. and M. Wilhelm (2000), Taxation and the labor supply decisions of the affluent, in Slemrod, J. (ed.), Does Atlas Shrug? The Economic Consequences of Taxing the Rich, New York: Harvard University Press and Russel Sage Foundation.

Oswald, A. (1983), Altruism, jealousy, and the theory of optimal non-linear taxation, Journal of Public Economics 20, 77-88.

Parker, S., Belghitar, Y. and T. Barmby (2005), Wage uncertainty and the labour supply of self-employed workers, Economic Journal 115, C190-C207.

Petrova, M. (2008), Inequality and media capture, Journal of Public Economics 92, 183-212.

Sabirianova Peter, K., Buttrick, S. and D. Duncan (2010), Global reform of personal income taxation, 1981-2005, National Tax Journal 63, 447-478.

Saez, E. (2001), Using elasticities to derive optimal income tax rates, Review of Economic Studies 68, 205-229.

Saez, E., Slemrod, J. and S. Giertz (2011), The elasticity of taxable income with respect to marginal tax rates: A critical review, forthcoming in Journal of Economic Literature.

Simula, L. and A. Trannoy (2010), Optimal income tax under the threat of migration by top-income earners, Journal of Public Economics 94, 163-173.

Slemrod, J. (1994), On the high-income Laffer curve, in Slemrod, J. (ed.), Tax Progressivity and Income Inequality, Cambridge: Harvard University Press.

Steiner, V. and K. Wrohlich (2008), Introducing family tax splitting in Germany: How would it affect the income distribution, work incentives and household welfare? Finanzarchiv - Public Finance Analysis 64, 115-142.

Tuomala, M. (1984), On the optimal income taxation: Some further numerical results, Journal of Public Economics 23, 351-66. 
van Soest, A. (1995), Structural models of family labor supply: A discrete choice approach, Journal of Human Resources 30, 63-88.

Varian, H. (1980), Redistributive taxation as social insurance, Journal of Public Economics 14, 49-68.

Yitzhaki, S. (1979), Relative deprivation and the Gini coefficient, Quarterly Journal of Economics 93, 321-4.

Young, C. and C. Varner (2011), Millionaire migration and state taxation of top incomes: Evidence from a natural experiment, National Tax Journal 64, 255-283. 


\section{Diskussionsbeiträge \\ des Fachbereichs Wirtschaftswissenschaft \\ der Freien Universität Berlin}

2011

2011/1 NEHER, Frank

Markets Wanted - Expectation Overshooting in Transition

Economics

2011/2 KNOLL, Martin / Petra ZLOCZYSTI

The Good Governance Indicators of the Millennium Challenge

Account

Economics

2011/3 KAPPLER, Marcus / Helmut REISEN / Moritz SCHULARICK /

Edouard TURKISCH

The Macroeconomic Effects of Large Exchange Rate Appreciations Economics

2011/4 MÜLLER, Kai-Uwe / Viktor STEINER

Beschäftigungswirkungen von Lohnsubventionen und Mindestlöhnen Economics

2011/5 WRAGE, Markus / Anja TUSCHKE / Rudi K. F. BRESSER

The Influence of Social Capital on CEO Dismissal in Germany

Strategic Management

2011/6 BLAUFUS, Kay / Sebastian EICHFELDER / Jochen

HUNDSDOERFER

The hidden burden of the income tax

FACTS

2011/7 MUCHLINSKI, Elke

Die Rezeption der John Maynard Keynes Manuskripte von 1904 bis 1911

Economics

2011/8 FOSSEN, Frank M.

Personal bankcuptcy law, wealth and entrepreneurship - Theory and evidence from the introduction of a "fresh start"

Economics

2011/9 CALIENDO, Marco / Frank FOSSEN / Alexander KRITIKOS

Personality characteristics and the decision to become and stay

self-employed

Economics 
2011/10 BACH, Stefan / Martin BEZNOSKA / Viktor STEINER A Wealth Tax on the Rich to Bring Down Public Debt? Economics

2011/11 HETSCHKO, Clemens / Andreas KNABE / Ronnie SCHÖB Changing Identity: Retiring from Unemployment Economics

2011/12 BÖRNER, Lars / Battista SEVERGNINI Epidemic Trade

Economics

2011/13 SIELAFF, Christian

Steuerkomplexität und Arbeitsangebot - Eine experimentelle Analyse FACTS

2011/14 SCHÖB, Ronnie / Marcel THUM

Job Protection Renders Minimum Wages Less Harmful Economics

2011/15 GLOCKER, Daniela / Viktor STEINER

Returns to Education across Europe

Economics

2011/16 CORNEO, Giacomo

A Note on the Taxation of Couples Under Income Uncertainty Economics

2011/17 ENGLER, Philipp / WULFF, Alexander Opposition to Capital Market Opening Economics

2011/18 BACH, Stefan / Giacomo CORNEO / Viktor STEINER Effective taxation of top incomes in Germany Economics

2011/19 DWENGER, Nadja / Pia RATTENHUBER / Viktor STEINER Sharing burden: Empirical evidence on corporate tax incidence Economics

2011/20 BESTER, Helmut / Juri DEMUTH Signalling Rivalry and Quality Uncertainty in a Duopoly Economics

2011/21 BACH, Stefan / Giacomo CORNEO / Viktor STEINER Optimal Top Marginal Tax Rates under Income Splitting for Couples Economics 